University of Nebraska - Lincoln

DigitalCommons@University of Nebraska - Lincoln

USGS Staff -- Published Research

US Geological Survey

2004

\title{
The probable importance of snow and sediment shielding on cosmogenic ages of north-central Colorado Pinedale and pre-Pinedale moraines
}

Larry Benson

University of Colorado at Boulder, great.basin666@gmail.com

Richard Madole

US Geological Survey

William Phillips

University of Edinburgh

Gary Landis

US Geological Survey

Terry Thomas

New Mexico Bureau of Geology

See next page for additional authors

Follow this and additional works at: http://digitalcommons.unl.edu/usgsstaffpub

Benson, Larry; Madole, Richard; Phillips, William; Landis, Gary; Thomas, Terry; and Kubik, Peter, "The probable importance of snow and sediment shielding on cosmogenic ages of north-central Colorado Pinedale and pre-Pinedale moraines" (2004). USGS Staff -Published Research. 788.

http:// digitalcommons.unl.edu/usgsstaffpub/788

This Article is brought to you for free and open access by the US Geological Survey at DigitalCommons@University of Nebraska - Lincoln. It has been accepted for inclusion in USGS Staff -- Published Research by an authorized administrator of DigitalCommons@University of Nebraska - Lincoln. 


\section{Authors}

Larry Benson, Richard Madole, William Phillips, Gary Landis, Terry Thomas, and Peter Kubik 


\title{
The probable importance of snow and sediment shielding on cosmogenic ages of north-central Colorado Pinedale and pre-Pinedale moraines
}

\author{
Larry Benson ${ }^{\mathrm{a}, *}$, Richard Madole ${ }^{\mathrm{b}}$, William Phillips ${ }^{\mathrm{c}}$, Gary Landis ${ }^{\mathrm{d}}$, \\ Terry Thomas ${ }^{\mathrm{e}}$, Peter Kubik ${ }^{\mathrm{f}}$ \\ ${ }^{a}$ US Geological Survey, 3215 Marine Street, Boulder, CO 80303-1066, USA \\ ${ }^{\mathrm{b}}$ US Geological Survey, MS 980, Denver Federal Center, Lakewood, CO 80225, USA \\ ${ }^{\mathrm{c}}$ School of Earth, Environmental and Geographical Sciences, Drummond Street, University of Edinburgh, Scotland EH8 9XP, UK \\ ${ }^{\mathrm{d}}$ US Geological Survey, MS 963, Denver Federal Center, Lakewood, CO 80225, USA \\ ${ }^{\mathrm{e}}$ New Mexico Bureau of Geology, 801 Leroy Place, Socorro, NM 87801, USA \\ ${ }^{\mathrm{f}}$ Paul Scherrer HPK H30, ETH Institut of Particle Physics, Hönggerberg, Zurich CH-8093, Switzerland
}

Received 24 February 2003; accepted 15 July 2003

\begin{abstract}
Eight uncorrected ${ }^{36} \mathrm{Cl}$ ages for Pinedale boulders in north-central Colorado fall in the range 16.5 to $20.9 \mathrm{kyr}$. ${ }^{10} \mathrm{Be}$ age determinations on four of five boulders are in close agreement ( $\leqslant 6 \%$ difference) with ${ }^{36} \mathrm{Cl}$ determinations. Hypothetical corrections for snow shielding increased the ${ }^{36} \mathrm{Cl}$ ages of Pinedale boulder surfaces by an average of $\sim 12 \%$. Most ages for pre-Pinedale (Bull Lake) boulders fall within marine-isotope stage (MIS) 5, a time when continental and Sierran ice accumulations were small or nonexistent. Under the assumption that these boulders were deposited on moraines that formed before the end of MIS 6 ( $\sim 140 \mathrm{kyr}$ $\mathrm{BP})$, calculations indicated that rock-surface erosion rates would have had to range from 5.9 to $10.7 \mathrm{~mm} \mathrm{kyr}^{-1}$ to $\mathrm{produce}$ the observed ${ }^{36} \mathrm{Cl}$ values. When compared to rates that have been documented for the past $20 \mathrm{kyr}$, these erosion rates are extremely high. Snow shielding accounts for $0-48 \%$ of the additional years needed to shift pre-Pinedale dates to MIS 6 . This suggests that some combination of snow shielding, sediment shielding, or ${ }^{36} \mathrm{Cl}$ leakage has greatly decreased the apparent ages of most pre-Pinedale boulders. Inability to account for the effects of these processes seriously hinders the use of cosmogenic ages of pre-Pinedale boulders as estimators of the timing of alpine glaciation.
\end{abstract}

Published by Elsevier Ltd.

\section{Introduction}

Cosmogenic dating has the potential for filling large gaps in our understanding of the late Quaternary glacial chronology of the Colorado Rockies. Prior to the application of cosmogenic dating, the timing of Pinedale glacial events was estimated from a few ${ }^{14} \mathrm{C}$ dates determined on the organic component of lake and fen sediments that accumulated in depressions on or adjacent to glacial deposits (Table 1). Most of these ${ }^{14} \mathrm{C}$ dates provide only minimum age estimates of glacial events. In addition, ${ }^{14} \mathrm{C}$ ages of organic material in till

*Corresponding author. Tel.: + 1-303-541-3005; fax: + 1-303-4472505 .

E-mail address: lbenson@usgs.gov (L. Benson). have not been reported for any locality in the northcentral Rocky Mountains.

Radiocarbon ages of basal sediment in fens and ponds located upvalley from terminal moraines have not been extremely useful in reconstructing glacial histories. Most ${ }^{14} \mathrm{C}$ ages from these settings do not date glacial events closely, and estimating the amount of time elapsed between deposition of glacial sediment and deposition of overlying lake or fen sediment is invariably problematic. Therefore, cosmogenic dates may better constrain the glacial histories of the valleys.

The purpose of this paper is to present the results of ${ }^{36} \mathrm{Cl}$ and ${ }^{10} \mathrm{Be}$ dating of boulders on Pinedale and prePinedale moraines in the Middle Boulder Creek, North St. Vrain, and Roaring Fork drainages (Figs. 1 and 2) of north-central Colorado, and to demonstrate the importance of snow and sediment shielding on the results. 
Table 1

Elevations and ${ }^{14} \mathrm{C}$ ages of samples used to approximate the advance and retreat of Pinedale glaciers in north-central Colorado

\begin{tabular}{|c|c|c|c|c|c|c|}
\hline Site & Locality & Ele.(m) & Sample material & ${ }^{14} \mathrm{C}$ age (kyr BP) & Lab number & Reference \\
\hline \multicolumn{7}{|c|}{ Basal sediment from ice-marginal lakes located near Pinedale terminal moraine } \\
\hline 1 & Devlin Park & 2956 & LOC & $22.40 \pm 1.23$ & DIC-870 & Madole (1986) \\
\hline 2 & Triangle Park & 2990 & LOC & $23.17 \pm 1.05$ & DIC-1170 & Rosenbaum and Larson (1983) \\
\hline \multicolumn{7}{|c|}{ Kettle pond (3) and fen (4) located on Pinedale terminal moraine } \\
\hline 3 & Winding River & 2640 & LOC & $13.82 \pm 0.81$ & GAK-4537 & Madole (1976b) \\
\hline 4 & Mary Jane & 2882 & Peat & $13.74 \pm 0.16$ & DIC-671 & Nelson et al. (1979) \\
\hline \multicolumn{7}{|c|}{ Fen on Continental Divide site of major transect glacier } \\
\hline 5 & La poudre Pass & 3092 & Peat & $9.85 \pm 0.30$ & W-4083 & Madole (1980) \\
\hline \multicolumn{7}{|c|}{ Ponds and fens located near center of Pinedale icecap } \\
\hline 6 & Buffalo Pass 1 & 3156 & LOC & $13.68 \pm 0.11$ & W-5028 & Madole (1986) \\
\hline 7 & Buffalo Pass 2 & 3168 & LOC & $11.76 \pm 0.10$ & W-5034 & Madole (unpublished) \\
\hline \multicolumn{7}{|c|}{ Lakes near cirques } \\
\hline 8 & Lake Dorothy & 3677 & $\mathrm{HOC}$ & $10.91 \pm 0.32$ & GX-17863 & Davis et al. (1992) \\
\hline 9 & Butterfly Lake & 3460 & LOC & $10.41 \pm 0.52$ & GX-11774 & Davis (1987) \\
\hline 10 & Blue Lake & 3442 & LOC & $12.28 \pm 0.34$ & GX-17878 & Davis et al. (1992) \\
\hline 11 & Sky Pond & 3323 & Beetle & $12.04 \pm 0.06$ & CAMS-22027 & Menounos and Reasoner (1997) \\
\hline 12 & Mitchell Lake & 3262 & LOC & $10.92 \pm 0.36$ & SI-5189 & Nichols et al. (1984) \\
\hline 13 & Long Lake & 3208 & LOC & $11.80 \pm 0.45$ & GX-7723 & Nichols et al. (1984) \\
\hline
\end{tabular}

LOC and HOC refer to sediments containing low and relatively high amounts of organic carbon. See Fig. 1 for site locations.

\section{Study area}

Samples for cosmogenic dating were collected on the crests of end moraines near the downvalley limit of glaciation in three valleys in north-central Colorado. Two of the valleys are located on the east slope of the Front Range and one valley is located on the east slope of the Park Range (Fig. 1). Front Range samples are from the North St. Vrain Creek and Middle Boulder Creek (Figs. 2A and 2B) drainages, and Park Range samples are from the Roaring Fork valley (Fig. 2C). Proterozoic granite and quartz monzonite are the dominant bedrock types in the glacier accumulation area in all three valleys (Gable, 1969; Snyder, 1980; Braddock and Cole, 1990).

Most Pleistocene glaciers in north-central Colorado originated in cirques and flowed down deep valleys. In a few places, valley glaciers drained small icecaps, the largest of which mantled the summit of the Park Range east of Steamboat Springs (Madole, 1976a, 1980, 1991a,b). The glacier in the Cache la Poudre River valley (Fig. 1) was $42 \mathrm{~km}$ long and as much as $600 \mathrm{~m}$ thick, but most valley glaciers in the region were less than half as large (Madole et al., 1998).

The typical Front Range glacier attained lengths of $10-20 \mathrm{~km}$ and thicknesses of $180-350 \mathrm{~m}$, and most terminated at elevations between 2500 and $2700 \mathrm{~m}$. Valley glaciers in the Park Range were similar in length and thickness to those in the Front Range. However, glaciers on the east slope of the Park Range generally were only $10-13 \mathrm{~km}$ long because the relatively flat floor of a high intermontane basin (North Park) limited their eastward descent. Most glaciers on the west slope of the Park Range terminated at elevations between 2130 and $2200 \mathrm{~m}$, which is much lower than their Front Range counterparts. Glaciers on the east slope of the Park Range terminated at elevations between 2530 and $2680 \mathrm{~m}$ (Madole 1991a,b). These glaciers tended to spread broadly and form sets of massive end moraines.

Many Front Range valleys are so deep and narrow that glaciers were unable to overtop valley walls and, consequently, lateral moraines are not well preserved. Most pre-Pinedale till in these valleys was overridden by Pinedale glaciers or was buried by valley-side colluvium. However, in those valleys where glacier termini were able to spread laterally, deposits of two, and in some places possibly three, different glaciations are preserved. In order of increasing age, the two widely recognized deposits are referred to as Pinedale and Bull Lake (Madole, 1976a; Madole et al., 1998). The relative ages of the deposits are based on differences in areal extent, stratigraphic position, topographic expression, and degree of weathering (Madole et al., 1998).

Pinedale deposits mantle $75-90 \%$ of the glaciated area. These deposits have a distinctive morphology that includes high (20-30 m), sharp-crested moraines, knoband-kettle topography, and numerous fens and kettle ponds. The combined thickness of A and B horizons of soils in till of Pinedale age commonly ranges from as little as $50 \mathrm{~cm}$ near the downvalley limit of glaciation to 


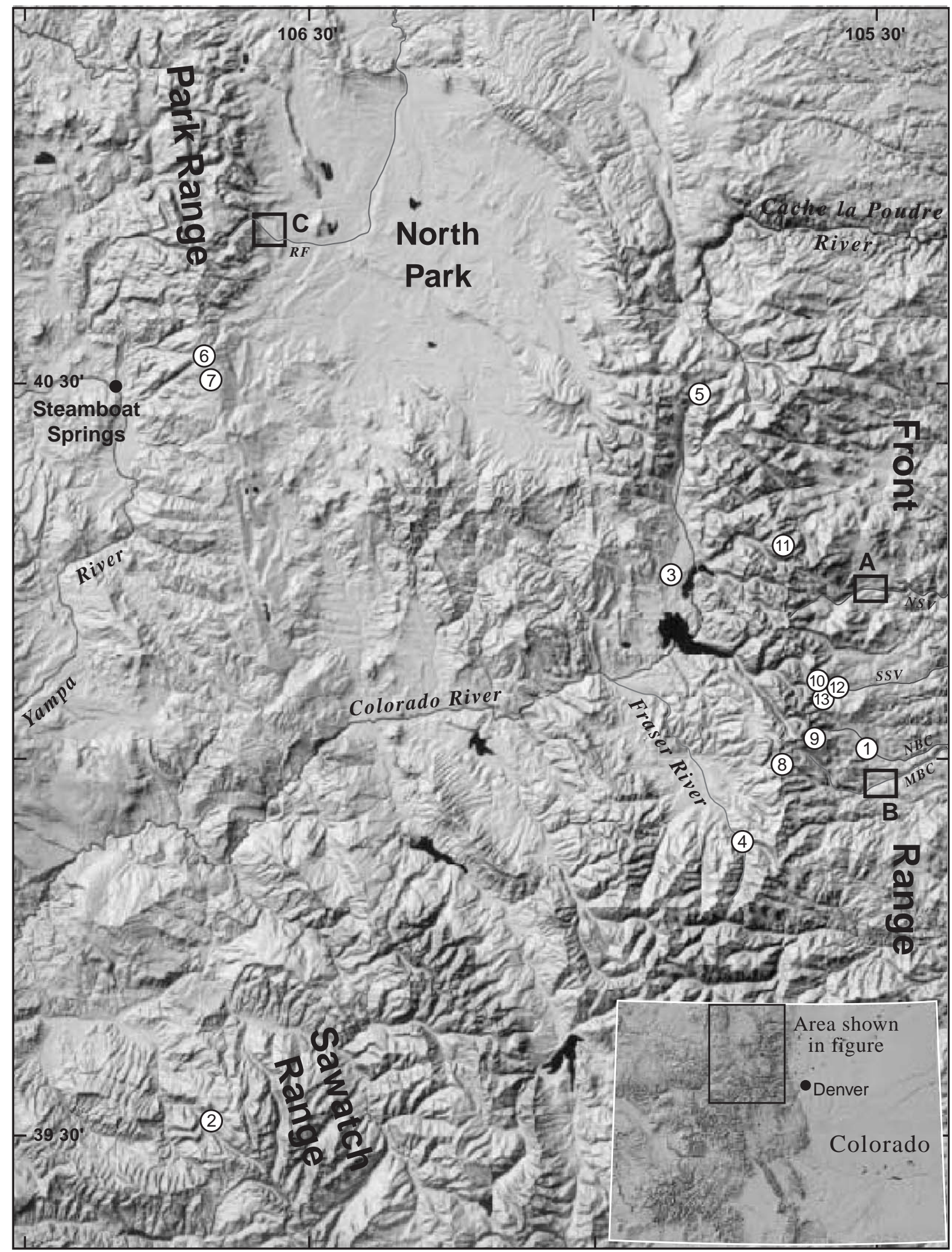

Fig. 1. Map showing locations of sample sites discussed in this paper. Circled numbers refer to sites listed in Table 1. Letters with boxes refer to locations of boulders sampled for cosmogenic dating in the North St. Vrain (NSV) drainage (A), Middle Boulder Creek (MBC) drainage (B), and Roaring Fork (RF) drainage (C). South St. Vrain (SSV) and North Boulder (NBC) creeks also shown. 

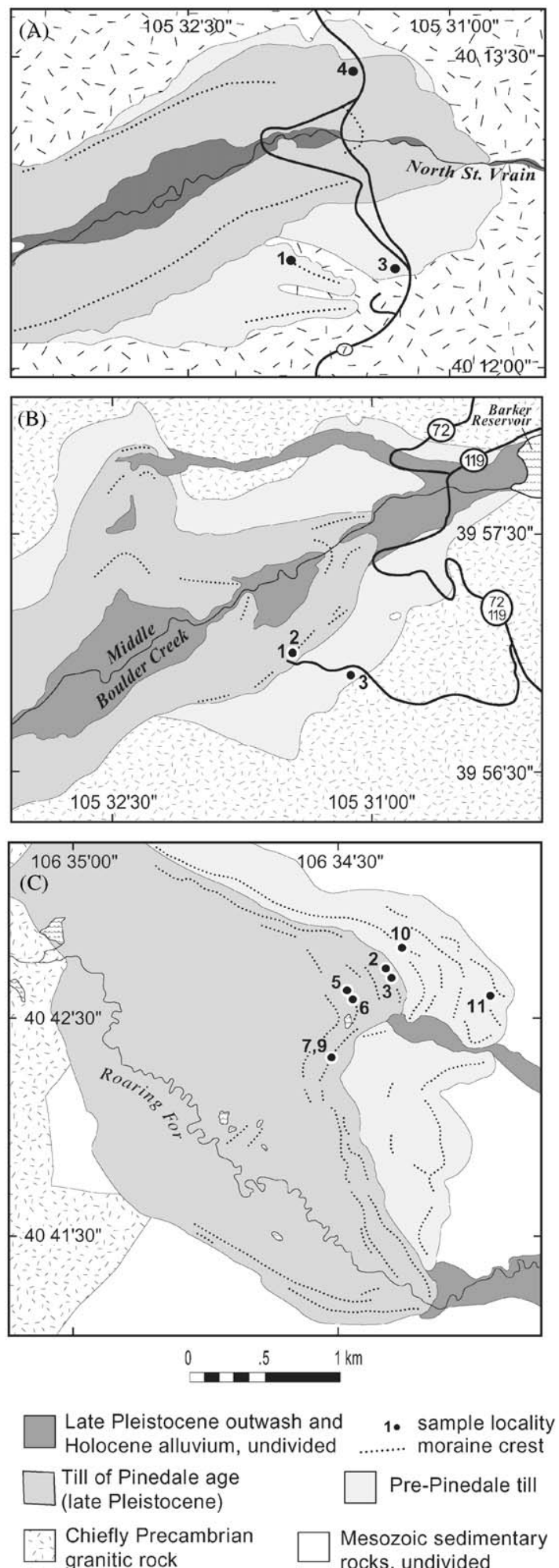

Fig. 2. Maps showing locations of boulders sampled for cosmogenic dating in the (A). North St. Vrain drainage, (B). Middle Boulder Creek drainage, and (C). Roaring Fork drainage.

as much as $100 \mathrm{~cm}$ at higher $(>2900 \mathrm{~m})$ elevations (Madole 1969; Madole and Shroba, 1979). Weathering rinds in most clasts are $<3 \mathrm{~mm}$ thick and decomposed clasts are rare (Madole, 1969, 1976a). In contrast, end moraines of Bull Lake age are not as high or sharpcrested as are those of Pinedale age and, where preserved, knob-and-kettle topography is subdued and kettles rarely contain ponds. In addition, Bull Lake soils are much thicker $(1.5 \mathrm{~m})$ and more strongly developed than Pinedale soils, and $20-30 \%$ of the clasts in them are partly to completely decomposed (Madole, 1969, 1976a).

Although differences between deposits of Pinedale and Bull Lake age are pronounced, the same is not true for deposits older than Pinedale. Therefore, for the purposes of this paper, we will refer to Colorado glacial deposits that are older than Pinedale simply as prePinedale deposits.

\section{Radiocarbon-based estimates of the timing of Pinedale glaciation in north-central Colorado}

In this section we discuss and summarize ${ }^{14} \mathrm{C}$-based studies of Pinedale glaciation in north-central Colorado. The best estimate for the initiation of Pinedale glaciation comes from the Mary Jane site located in the Fraser River valley (Fig. 1, Table 1) (Nelson et al., 1979). A sequence of interbedded diamicton, peat, and lacustrine sediment was exposed in a pit $\left(15 \times 18 \times 12 \mathrm{~m}^{3}\right)$ excavated for the foundation of a ski-lift tower. A thin, discontinuous bed of lake sediment with an age of $30.1 \pm 1.2{ }^{14} \mathrm{C}(35.1 \mathrm{cal}){ }^{1} \mathrm{kyr} \mathrm{BP}$ was found sandwiched between diamicton beds that may correspond to the initial Pinedale advance. However, given the restricted area of viewable outcrop, it is not possible to completely rule out a landslide origin for the basal diamicton.

Because the inception of ice-marginal lakes is directly linked to glacier movement, the ${ }^{14} \mathrm{C}$ ages of organic matter from basal sediments of such lakes tend to date glacial events more closely than the ${ }^{14} \mathrm{C}$ ages of organic matter from lake and fen sediments located in depressions on glacial deposits. Thus, ${ }^{14} \mathrm{C}$ dates from two icemarginal paleolakes allow us to approximate the time of greatest expansion of Pinedale ice. Glacial Lake Devlin formed when the North Boulder Creek valley glacier blocked the mouth of a tributary located $2.3 \mathrm{~km}$ upvalley from the Pinedale terminal moraine. The inception of Lake Devlin, which occurred at or before $22.4 \pm 1.1{ }^{14} \mathrm{C}(26.4 \mathrm{cal}) \mathrm{kyr}$ BP (Fig. 1, Table 1), provides a limiting date for the maximum expansion of Pinedale ice (Legg and Baker, 1980; Madole, 1986). Triangle

\footnotetext{
${ }^{114} \mathrm{C}$ ages between 9.0 and $12.0 \mathrm{kyr}$ were converted to calendar (cal) yr using a second degree polynomial fit to the Cariaco Basin data of Hughen et al. (1998), and ${ }^{14} \mathrm{C}$ ages between 12.0 and $30.1 \mathrm{kyr}$ were converted to calendar yr using a second degree polynomial fit to the coral-based data of Bard et al. (1998). The error in the calendar age is not shown and is assumed to be about the same as the error in the ${ }^{14} \mathrm{C}$ age.
} 
Park, in the northern end of the Sawatch Range, was also the site of an ice-marginal lake that was dammed by a Pinedale glacier (Rosenbaum and Larson, 1983). Lake-bottom sediments from this site, located $0.9 \mathrm{~km}$ upstream from the Pinedale terminal moraine, date to $23.2 \pm 1.0{ }^{14} \mathrm{C}$ (27.4 cal) kyr BP (Fig. 1, Table 1).

Two sites from terminal-moraine complexes indicate that the lag times between the retreat of Pinedale glaciers and the accumulation of datable organic carbon amounted to a few thousand years. For example, bottom sediment from the Winding River kettle located on the Pinedale terminal moraine $(2640 \mathrm{~m})$ in the upper Colorado River valley yielded a date of $13.8 \pm 0.8{ }^{14} \mathrm{C}$ (16.2 cal) kyr BP (Madole, 1976b). Peat that overlies lake sediment deposited at the Mary Jane site (2882 m) in the Fraser River valley yielded a date of $13.74 \pm 0.16$ ${ }^{14} \mathrm{C}$ (16.13 cal) kyr BP (Nelson et al., 1979).

Pinedale glaciers probably disappeared from the Front Range sometime after $13.7{ }^{14} \mathrm{C}(16.1 \mathrm{cal})$ and before $11.8{ }^{14} \mathrm{C}(13.8 \mathrm{cal}) \mathrm{kyr} \mathrm{BP}$. The older limit is based on a date of $13.68 \pm 0.11{ }^{14} \mathrm{C}(16.05 \mathrm{cal}) \mathrm{kyr}$ BP for the deglaciation of an area located $1 \mathrm{~km}$ west of Buffalo Pass (Madole, 1986), which was near the divide mantled by the Pinedale icecap. The younger limit is based on a lake-sediment ${ }^{14} \mathrm{C}$ age of $11.76 \pm 0.10{ }^{14} \mathrm{C}(13.77 \mathrm{cal}) \mathrm{kyr}$ BP from a site located on the Continental Divide $\sim 1.5 \mathrm{~km}$ south of Buffalo Pass (Madole, 1980) (Fig. 1, Table 1). La Poudre Pass, a site on the divide of a transection glacier (the largest glacier in the Front Range) that flowed north into the Cache la Poudre River valley and south into the Colorado River valley, was completely ice free by $\sim 10.0{ }^{14} \mathrm{C}(11.6 \mathrm{cal}) \mathrm{kyr} \mathrm{BP}$ (Fig. 1, Table 1).

Basal sediments from Front Range cirques have yielded dates indicating the disappearance of Pinedale glaciers prior to $12.0{ }^{14} \mathrm{C}(14.0 \mathrm{cal}) \mathrm{kyr}$ BP. Davis et al. (1992) reported a date of $12.28 \pm 0.34{ }^{14} \mathrm{C}(14.4 \mathrm{cal}) \mathrm{kyr}$ from basal sediment in Blue Lake, a high-elevation $(3450 \mathrm{~m})$ body of water located at the head of the South St. Vrain Creek drainage basin (Fig. 1, Table 1). In addition, Menounos and Reasoner (1997) obtained a date of $12.04 \pm 0.06{ }^{14} \mathrm{C}(14.0$ cal $)$ kyr BP on basal sediment from Sky Pond, another high-elevation $(3320 \mathrm{~m})$ lake located in the upper part of the Glacier Creek drainage basin (Fig. 1, Table 1).

Additional dates on basal and near-basal sediment from lakes and fens from relatively high-elevation $(>3000 \mathrm{~m})$ sites in north-central Colorado fall within a $10.4{ }^{14} \mathrm{C}(12.2 \mathrm{cal})$ to $12.3{ }^{14} \mathrm{C}(14.4 \mathrm{cal}) \mathrm{kyr} \mathrm{BP}$ age range (Table 1). We believe that all dates on lake and fen sediments lag the retreat of the Pinedale glaciation by several hundred to a few thousand years, the time it took for abundant vegetation (the source of ${ }^{14} \mathrm{C}$-datable organic carbon) to be reestablished in surrounding watersheds. ${ }^{14} \mathrm{C}$ dates on peat and beetle fragments should be considered reliable; however, Reasoner and
Jodry (2000) found that two dates on bulk organic sediment from Black Mountain Lake in southern Colorado were 760 and $875 \mathrm{yr}$ older than terrestrial macrofossils from the same levels. Thus, the establishment times for some of the lakes and fens may be somewhat later than that estimated using ${ }^{14} \mathrm{C}$ dates obtained on organic carbon from their basal sediments.

To summarize, ${ }^{14} \mathrm{C}$ ages of near-basal sediments from lakes and ponds that formed on drift or that resulted from the damming of ice-marginal drainages indicate (1) formation of Pinedale glaciers was initiated $\geqslant 30{ }^{14} \mathrm{C}(35$ cal) kyr ago; (2) they were nearing their maximum extent $\sim 22{ }^{14} \mathrm{C}(26 \mathrm{cal}) \mathrm{kyr}$ ago; and (3) they had disappeared from all but the highest elevations of the Front Range by $\sim 14{ }^{14} \mathrm{C}(16.4$ cal $)$ kyr ago.

\section{Methods}

\subsection{Sample collection}

Samples were collected with hammer and chisel from tops of boulders located on or near moraine crests. The boulders are Middle Proterozoic granite and quartz monzonite, and ranged in height from 0.3 to $3.0 \mathrm{~m}$ (Table 2). The latitude, longitude, and elevation of each boulder was estimated using a hand-held GPS unit. The elevation estimate was further refined using sample locations plotted on topographic maps. The estimated horizontal accuracy was $3-5 \mathrm{~m}$ and the estimated vertical accuracy was better than $10 \mathrm{~m}$.

\section{2. ${ }^{36} \mathrm{Cl}$ determinations}

Samples for ${ }^{36} \mathrm{Cl}$ measurements were sawn to a thickness of $2.5-3.0 \mathrm{~cm}$. Lichens and other organic matter were removed from the surface before reducing the sample to $<1 \mathrm{~mm}$ fragments by grinding. The sample was then sieved to obtain the $>150 \mu \mathrm{m}$ to $<1 \mathrm{~mm}$ size fraction. The sample was leached in $3 \%$ $\mathrm{HNO}_{3}$ overnight to remove any secondary chloride and carbonate, rinsed in $18 \mathrm{M} \Omega$ water, brought to a basic $\mathrm{pH}$ using $1 \% \mathrm{NaOH}$, and rinsed several times in $18 \mathrm{M} \Omega$ water bringing it to a $\mathrm{pH}<7$. After oven drying at $<90^{\circ} \mathrm{C}$, aliquots for chemical analyses were removed and ground to a powder using a tungsten-carbide mill.

Major elements, including $\mathrm{U}$ and $\mathrm{Th}$, were determined by X-ray fluorescence, and $\mathrm{B}$ and $\mathrm{Gd}$ were measured by prompt-gamma-emission spectrometry (Table 3). The chloride concentration of the samples was initially estimated with an ion-selective electrode in a Teflon diffusion cell. This initial estimate was used to determine the mass of sample to be dissolved and the amount of stable chloride carrier $\left(99.5 \%{ }^{35} \mathrm{Cl}\right)$ to be added. The chloride concentrations used for age calculations were 
Table 2

Heights, snow depth and shielding, locations, elevations, and ${ }^{36} \mathrm{Cl}$ and ${ }^{10} \mathrm{Be}$ age estimations for boulders on moraine crests in the Middle Boulder Creek (MBC), North St. Vrain (NSV) and Roaring Fork (RF) watersheds. FP and JS production refers to ages obtained after application of ${ }^{36} \mathrm{C} 1$ production rates of Phillips et al. (1996, 2001), Stone et al. (1996) and Evans et al. (1997). Erosion rates refer to those rates necessary to increase the apparent of age of sample to $140 \mathrm{kyr}$

\begin{tabular}{|c|c|c|c|c|c|c|c|}
\hline Sample & Moraine type & $\begin{array}{l}\text { Boulder } \\
\text { height }(\mathrm{m})\end{array}$ & $\begin{array}{l}\text { Hist. Snow } \\
\text { mean depth } \\
(\mathrm{m})\end{array}$ & $\begin{array}{l}\text { Snow } \\
\text { shielding } \\
\text { value }\end{array}$ & Lat. & Long. & Ele.(m) \\
\hline MBC-01-1 & Pinedale & 0.6 & 0.53 & 0.922 & 39.9499 & 105.5244 & 2680 \\
\hline MBC-01-2 & Pinedale & 0.8 & 0.53 & 0.930 & 39.9492 & 105.5248 & 2660 \\
\hline MBC-01-3 & Pre-Pinedale & 0.3 & 0.53 & 0.931 & 39.9479 & 105.5201 & 2690 \\
\hline NSV-01-1 & Pre-Pinedale & 1 & 0.36 & 0.990 & 40.2089 & 105.5323 & 2650 \\
\hline NSV-01-3 & Pre-Pinedale & 3 & 0.36 & 1.000 & 40.2075 & 105.5219 & 2610 \\
\hline NSV-01-3dupe & Pre-Pinedale & 3 & 0.36 & 1.000 & 40.2075 & 105.5219 & 2610 \\
\hline NSV-01-4 & Pinedale & 1.1 & 0.36 & 0.977 & 40.2235 & 105.5262 & 2580 \\
\hline RF-01-2 & Pinedale & 1.4 & 0.97 & 0.881 & 40.7118 & 106.5534 & 2600 \\
\hline RF-01-3 & Pinedale & 1.2 & 0.97 & 0.875 & 40.7113 & 106.5534 & 2620 \\
\hline RF-01-5 & Pinedale & 1.5 & 0.97 & 0.885 & 40.7097 & 106.5562 & 2640 \\
\hline RF-01-6 & Pinedale & 0.9 & 0.97 & 0.865 & 40.7098 & 106.5564 & 2640 \\
\hline RF-01-7 & Pinedale & 0.5 & 0.97 & 0.853 & 40.7059 & 106.5588 & 2660 \\
\hline RF-01-9 & Pinedale & 1.6 & 0.97 & 0.888 & 40.7055 & 106.5588 & 2660 \\
\hline RF-01-10 & Pre-Pinedale & 1.2 & 0.97 & 0.909 & 40.7142 & 106.5526 & 2620 \\
\hline \multirow[t]{3}{*}{ RF-01-11 } & Pre-Pinedale & 1.5 & 0.97 & 0.921 & 40.7149 & 106.5507 & 2620 \\
\hline & & \multicolumn{5}{|l|}{${ }^{36} \mathrm{Cl}$ ages $(\mathrm{kyr})$} & $\begin{array}{l}{ }^{10} \mathrm{Be} \text { ages } \\
(\mathrm{kyr})\end{array}$ \\
\hline & ${ }^{36} \mathrm{Cl} / 10{ }^{35} \mathrm{Cl}$ & $\begin{array}{l}0.0 \mathrm{~mm} \mathrm{kyr}^{-1} \\
\text { erosion, FP } \\
\text { production }\end{array}$ & $\begin{array}{l}0.5 \mathrm{~mm} / \\
1.0 \mathrm{~mm} \mathrm{kyr}^{-1} \\
\text { erosion, FP } \\
\text { production }\end{array}$ & $\begin{array}{l}\text { Erosion } \\
\text { corrected ages } \\
\text { Rate/age (mm } \\
\left.\mathrm{kyr}^{-1} / \mathrm{kyr}\right)\end{array}$ & $\begin{array}{l}\text { Snow shield } \\
\text { corrected }\end{array}$ & $\begin{array}{l}0.0 \mathrm{~mm} \mathrm{kyr}^{-1} \\
\text { erosion, JS } \\
\text { production }\end{array}$ & $\begin{array}{l}0.0 \mathrm{~mm} \mathrm{kyr}^{-1} \\
\text { erosion }\end{array}$ \\
\hline MBC-01-1 & 384.4 & 17.5 & $17.0 / 16.5$ & & 19.1 & 18.5 & \\
\hline MBC-01-2 & 486.7 & 20.9 & $20.5 / 20.1$ & & 22.5 & 20.1 & \\
\hline MBC-01-3 & 1556 & 144 & & & 157 & 143 & \\
\hline NSV-01-1 & 2701 & 86.9 & & $10.7 / 140$ & 88 & & \\
\hline NSV-01-3 & 2512 & 127 & & $6.6 / 140$ & 127 & & \\
\hline NSV-01-3dupe & 2493 & 127 & & & 127 & & \\
\hline NSV-01-4 & 882.7 & 18.4 & $18.3 / 18.3$ & & 18.9 & & $19.7 \pm 1.3$ \\
\hline RF-01-2 & 692.6 & 25.8 & $25.3 / 24.8$ & & $28.1^{\mathrm{a}}$ & & $23.2 \pm 1.3$ \\
\hline RF-01-3 & 702.1 & 19.3 & $19.0 / 18.8$ & & 22.1 & & \\
\hline RF-01-5 & 643.9 & 19.3 & $19.0 / 18.9$ & & 21.8 & & $20.1 \pm 1.1$ \\
\hline RF-01-6 & 716.5 & 16.5 & $16.4 / 16.3$ & & 19.1 & & \\
\hline RF-01-7 & 673.4 & 17.2 & $17.0 / 16.9$ & & 20.2 & & \\
\hline RF-01-9 & 497.5 & 18.4 & $18.2 / 17.9$ & & 20.8 & & $18.4 \pm 1.0$ \\
\hline RF-01-10 & 2954 & 92.6 & & & 103 & & $92.8 \pm 5.7$ \\
\hline RF-01-11 & 4062 & 117 & & $5.9 / 140$ & 128 & & \\
\hline
\end{tabular}

${ }^{\text {a }}$ Shielding correction was added to the mean of the ${ }^{36} \mathrm{Cl}$ and ${ }^{10} \mathrm{Be}$ ages.

determined by accelerator mass spectrometry (AMS) using isotope-dilution mass spectrometry.

To extract $\mathrm{Cl}$ for ${ }^{36} \mathrm{Cl}$ analyses, a 5:1 mixture of $\mathrm{HF}$ and $\mathrm{HNO}_{3}$ was added to Teflon bottles, containing 20 $200 \mathrm{~g}$ (depending on initial $\mathrm{Cl}$ concentration) of leached sample. The bottles were allowed to sit on a warm hotplate for approximately 5 days to assure complete dissolution. After centrifugation, the supernatant was poured into Teflon beakers and $\mathrm{AgNO}_{3}$ was added to precipitate $\mathrm{AgCl}$. Sulfur removal ${ }^{36} \mathrm{~S}$ is an isobar of ${ }^{36} \mathrm{Cl}$ ) was accomplished by redissolving the $\mathrm{AgCl}$ with $\mathrm{NH}_{4} \mathrm{OH}$ and adding $\mathrm{Ba}\left(\mathrm{NO}_{3}\right)_{2}$ to precipitate $\mathrm{BaSO}_{4}$. The sample was centrifuged, the solution placed in a clean centrifuge tube, and $\mathrm{AgCl}$ was reprecipitated by adding $\mathrm{HNO}_{3}$. The samples were brought to neutral $\mathrm{pH}$ by centrifuging and rinsing in $18 \mathrm{M} \Omega$ and dried on covered watch glasses in an oven at $<70^{\circ} \mathrm{C}$.

${ }^{36} \mathrm{Cl} /{ }^{37} \mathrm{Cl}$ and ${ }^{35} \mathrm{Cl} /{ }^{37} \mathrm{Cl}$ ratios of the purified $\mathrm{AgCl}$ precipitate were measured at the Center of Accelerator Mass Spectrometry facility at the Lawrence Berkeley National Laboratory under the supervision of R. Finkel. ${ }^{36} \mathrm{Cl}$ surface-exposure ages were calculated using the most recent version of the CHLOE program (Phillips and Plummer, 1996). Muon production in CHLOE is based on the work of Evans et al. (1998). In CHLOE the calculation of low-energy neutron absorption, the 
Table 3

Chemical compositions of boulders sampled on moraine crests in the Middle Boulder Creek (MBC), North St. Vrain (NSV) and Roaring Fork (RF) watersheds

\begin{tabular}{|c|c|c|c|c|c|c|c|c|c|c|c|}
\hline Sample & $\begin{array}{l}\mathrm{SiO}_{2} \\
(\mathrm{wt} \%)\end{array}$ & $\begin{array}{l}\mathrm{TiO}_{2} \\
(\mathrm{wt} \%)\end{array}$ & $\begin{array}{l}\mathrm{Al}_{2} \mathrm{O}_{3} \\
(\mathrm{wt} \%)\end{array}$ & $\begin{array}{l}\mathrm{Fe}_{2} \mathrm{O}_{3}-\mathrm{T} \\
(\mathrm{wt} \%)\end{array}$ & $\begin{array}{l}\mathrm{MnO} \\
(\mathrm{wt} \%)\end{array}$ & $\begin{array}{l}\mathrm{MgO} \\
(\mathrm{wt} \%)\end{array}$ & $\begin{array}{l}\mathrm{CaO} \\
(\mathrm{wt} \%)\end{array}$ & $\begin{array}{l}\mathrm{K}_{2} \mathrm{O} \\
(\mathrm{wt} \%)\end{array}$ & $\begin{array}{l}\mathrm{Na}_{2} \mathrm{O} \\
(\mathrm{wt} \%)\end{array}$ & $\begin{array}{l}\mathrm{P}_{2} \mathrm{O}_{5} \\
(\mathrm{wt} \%)\end{array}$ & $\begin{array}{l}\text { LOI } \\
(w t \%)\end{array}$ \\
\hline MBC-01-1 & 74.96 & 0.09 & 14.41 & 1.60 & 0.01 & 0.30 & 3.31 & 0.51 & 4.58 & 0.01 & 0.25 \\
\hline MBC-01-2 & 72.22 & 0.40 & 14.06 & 2.82 & 0.03 & 0.48 & 1.03 & 5.34 & 3.03 & 0.04 & 0.53 \\
\hline MBC-01-3 & 64.96 & 0.99 & 16.24 & 5.94 & 0.07 & 1.25 & 2.68 & 3.44 & 3.79 & 0.13 & 0.37 \\
\hline NSV-01-1 & 75.33 & 0.32 & 12.78 & 2.01 & 0.02 & 0.40 & 0.83 & 5.35 & 2.58 & 0.10 & 0.31 \\
\hline NSV-01-3 & 70.94 & 0.48 & 14.65 & 5.22 & 0.05 & 1.04 & 0.66 & 5.00 & 2.01 & 0.10 & 0.23 \\
\hline NSV-01-4 & 76.90 & 0.18 & 12.84 & 1.08 & 0.01 & 0.23 & 0.65 & 5.67 & 2.70 & 0.11 & 0.33 \\
\hline RF-01-2 & 76.11 & 0.16 & 13.21 & 1.27 & 0.03 & 0.21 & 1.12 & 4.50 & 3.44 & 0.01 & 0.39 \\
\hline RF-01-3 & 76.19 & 0.17 & 13.38 & 1.32 & 0.03 & 0.21 & 1.02 & 4.50 & 3.53 & 0.02 & 0.37 \\
\hline RF-01-5 & 77.05 & 0.12 & 12.77 & 1.21 & 0.03 & 0.18 & 0.88 & 4.41 & 3.44 & 0.02 & 0.30 \\
\hline RF-01-6 & 75.21 & 0.21 & 13.13 & 1.99 & 0.04 & 0.30 & 1.03 & 4.50 & 3.43 & 0.02 & 0.50 \\
\hline RF-01-7 & 78.59 & 0.09 & 12.65 & 0.46 & 0.01 & 0.09 & 0.51 & 3.93 & 4.11 & 0.02 & 0.37 \\
\hline RF-01-9 & 74.25 & 0.29 & 13.76 & 2.14 & 0.04 & 0.27 & 1.43 & 3.47 & 4.05 & 0.02 & 0.33 \\
\hline RF-01-10 & 76.03 & 0.11 & 13.04 & 1.14 & 0.02 & 0.13 & 0.87 & 4.56 & 3.49 & 0.03 & 0.33 \\
\hline \multirow[t]{2}{*}{ RF-01-11 } & 80.41 & 0.04 & 11.22 & 0.53 & 0.00 & 0.03 & 0.18 & 4.47 & 3.52 & 0.01 & 0.16 \\
\hline & $\mathrm{Cl}(\mathrm{ppm})$ & $\mathrm{Ba}(\mathrm{ppm})$ & $\mathrm{Rb}(\mathrm{ppm})$ & $\mathrm{Sr}(\mathrm{ppm})$ & $\mathrm{Pb}(\mathrm{ppm})$ & Th (ppm) & $\mathrm{U}(\mathrm{ppm})$ & B (ppm) & Gd (ppm) & & Total (wt \%) \\
\hline MBC-01-1 & 101 & 56 & 25 & 343 & 13 & 12.6 & 11 & $<3$ & 2 & & 100.0 \\
\hline MBC-01-2 & 123 & 1020 & 217 & 270 & 33 & 36.7 & 2 & $<3$ & 4 & & 100.0 \\
\hline MBC-01-3 & 325 & 1130 & 180 & 426 & 27 & 59.4 & 3 & $<3$ & 10 & & 99.9 \\
\hline NSV-01-1 & 106 & 416 & 314 & 103 & 35 & 23.9 & 3 & $<3$ & 4 & & 100.0 \\
\hline NSV-01-3 & 159 & 575 & 197 & 132 & 37 & 12.9 & 3 & $<3$ & 5 & & 100.4 \\
\hline NSV-01-4 & 49 & 318 & 244 & 68 & 32 & 6.6 & 1 & $<3$ & 2 & & 100.7 \\
\hline RF-01-2 & 89 & 826 & 167 & 161 & 21 & 4.4 & 3 & $<3$ & 1 & & 100.5 \\
\hline RF-01-3 & 78 & 711 & 196 & 144 & 27 & 16.7 & 5 & $<3$ & 2 & & 100.7 \\
\hline RF-01-5 & 64 & 560 & 210 & 112 & 24 & 2.8 & 3 & $<3$ & 2 & & 100.4 \\
\hline RF-01-6 & 50 & 880 & 189 & 170 & 21 & 20.1 & 3 & $<3$ & 4 & & 100.4 \\
\hline RF-01-7 & 52 & 646 & 134 & 139 & 14 & 11.4 & 6 & 3 & 1 & & 100.8 \\
\hline RF-01-9 & 76 & 984 & 156 & 249 & 19 & 6 & 2 & $<3$ & 3 & & 100.0 \\
\hline RF-01-10 & 79 & 841 & 184 & 162 & 24 & 9.2 & 2 & $<3$ & 3 & & 99.8 \\
\hline RF-01-11 & 53 & 136 & 205 & 23 & 17 & 7.1 & 9 & $<3$ & 3 & & 100.6 \\
\hline
\end{tabular}

quantification of the flux distribution, and its dependence on chemical composition is based on work discussed in Phillips et al. (2001). Spallation production constants for ${ }^{36} \mathrm{Cl}$ from $\mathrm{Ca}$ and $\mathrm{K}(66.8$ and 154 atoms $\mathrm{g}^{-1} \mathrm{yr}^{-1}$ ) derived by Phillips et al. (1996, 2001) were used in all age calculations. In addition, spallation production constants for ${ }^{36} \mathrm{Cl}$ from $\mathrm{Ca}$ and $\mathrm{K}$ (48.8 and 170 atoms $\mathrm{g}^{-1} \mathrm{yr}^{-1}$ ) derived by Stone et al (1996) and Evans et al. (1997) were applied to calculation of the ${ }^{36} \mathrm{Cl}$ ages of three Middle Boulder Creek samples. All ages were calculated using a bulk density of $2.7 \mathrm{~g} \mathrm{~cm}^{-3}$ and a neutron attenuation coefficient of $170 \mathrm{~g} \mathrm{~cm}^{-2}$. The analytical error for ${ }^{36} \mathrm{Cl}$ ages is assumed to be $\leqslant 8 \%$ of the age (Phillips et al., 1997). The $8 \%$ value is probably an overestimate of analytical error in this study; i.e., the reproducibility of two independent analyses of sample NSV-01-3 was excellent with no difference in age at the $3 \mathrm{rd}$ significant figure (Table 2). Chlorine analytical data are listed in
Appendix A of the electronic supplement to this paper.

\section{3. ${ }^{10}$ Be determinations}

Samples for ${ }^{10} \mathrm{Be}$ measurements were sawn to a uniform thickness $(4-5 \mathrm{~cm})$, crushed, and quartz concentrated from 250 to $500 \mu \mathrm{m}$ fraction using magnetic and heavy-liquid techniques. All samples were treated in $>1 \mathrm{M} \mathrm{HCl}$ on shaker table for $24 \mathrm{~h}$ to remove carbonates and oxide coatings on quartz. Samples were then rinsed in de-ionized water and air-dried. Pure quartz separates were prepared by etching concentrates in a solution of $2 \% \mathrm{HF}$ and $1 \% \mathrm{HNO}_{3}$ over a 5 -day period in an ultrasonic bath. The concentrate-tosolution ratio was $7 \mathrm{~g} / 1$. Acids were changed daily. This process yielded nearly pure quartz with trace amounts of a metallic sulfide that were removed by hand. 
From 20 to $30 \mathrm{~g}$ of quartz separate were dissolved in $\mathrm{HF}$ and spiked with $300 \mu \mathrm{g}$ of Be carrier (Spectrosol Be standard $1000 \mathrm{mg} / 1$ with a ${ }^{10} \mathrm{Be} /{ }^{9} \mathrm{Be}$ ratio of $2.3 \times 10^{-14}$ ). A procedural blank consisting of pure carrier was run at the same time as the samples. Be was separated from other species (chiefly $\mathrm{Fe}, \mathrm{Al}$, and $\mathrm{Ti}$ ) using ion-exchange columns and precipitation of $\mathrm{Be}(\mathrm{OH})_{2}$ at a $\mathrm{pH}$ of $8.5-$ 9.0. The hydroxide was converted to $\mathrm{BeO}$ by firing in a quartz crucible over an open flame until incandescent. Powdered $\mathrm{Ag}$ was mixed with $\mathrm{BeO}$ in the crucible and pressed into a cathode for analysis by AMS.

AMS analyses were conducted at the PSI/ETH AMS facility with a terminal voltage of $5.8 \mathrm{MV}$. The reported isotope ratios were normalized to Be standard S555 with a nominal value of ${ }^{10} \mathrm{Be} / \mathrm{Be}=95.5 \times 10^{-12}$. All ages were corrected for the carrier blank and for sample thickness using a bulk density of $2.7 \mathrm{~g} \mathrm{~cm}^{-3}$ and a neutron attenuation coefficient of $170 \mathrm{~g} \mathrm{~cm}^{-2}$.

Exposure ages were computed using a ${ }^{10} \mathrm{Be}$ production rate of $5.37 \pm 0.22$ atom $^{-1} \mathrm{yr}^{-1}$ at sea level and high latitude (SLHL). This production rate is from calibration sites in Austria (Kubik et al., 1998; Schaller et al., 2001) and Wyoming (Klein and Gosse, 2002) that are the best available matches for the latitude, elevation, and exposure time of our Colorado sites described in this paper. Production rates were scaled from SLHL to our Colorado sites using the procedures of Stone (2000), with the fraction of production by neutron spallation set at 0.974 . Errors $(1 \sigma)$ are analytical (AMS and target chemistry) uncertainties plus the error reported for the SLHL production rate.

No correction was made of dipole-induced variability of production rates. Geographic latitude was used in scaling of Colorado production rates in that production rates at mid-latitudes are not thought to be sensitive to geomagnetic field strength (Cerling and Craig, 1994; Phillips et al., 1996). Beryllium analytical data have been listed in Appendix B of the electronic supplement to this paper.

\subsection{Snow-shielding calculations}

To examine the effect of snow shielding on the apparent (measured) ages of Pinedale and pre-Pinedale boulders, the mean snow cover for the past $\sim 25 \mathrm{kyr}$ and $\sim 140 \mathrm{kyr}$ must be estimated. One way to approximate changes in snow cover is to determine changes in effective wetness ( $W_{\text {eff }}$ ) for a surface-water system that drains a mountainous area. Unfortunately paleohydrologic records of $W_{\text {eff }}$ are generally not available for much of the western US, but tend to be concentrated in the Great Basin (e.g., Oviatt et al., 1992; Benson et al., 1995). Obviously, changes in $W_{\text {eff }}$ of the Rockies of north-central Colorado have not necessarily paralleled changes in $W_{\text {eff }}$ of the Sierras or the Wasatch Mountains over the past 25 or $140 \mathrm{kyr}$. However, to illustrate the hypothetical importance of snow shielding on Colorado moraine-crest boulder ages we applied relative changes in $W_{\text {eff }}$ that occurred in the Sierra Nevada (as measured by changes in the hydrologic balances of Lake Lahontan and Owens Lake; Benson and Peterman, 1995; Benson et al., 1995, 2002; Menking et al., 1997; Benson, 2003) to the north-central Colorado. The boulder ages obtained after correction for snow shielding should be considered only as rough approximations given that snow-cover data are not available for our Colorado sites during the Pleistocene and Holocene.

The mean effective wetness $\left(\bar{W}_{\text {eff }}\right)$ for the Sierra Nevada during the past $25 \mathrm{kyr}$ was determined from direct sources (elevations of ${ }^{14} \mathrm{C}$-dated lacustrine carbonates) and indirect sources $\left({ }^{14} \mathrm{C}\right.$-dated core-based $\delta^{18} \mathrm{O}$ lacustrine records) of lake-level data compiled by Benson and Peterman (1995) and Benson et al. (1995, 2002). The $25-\mathrm{kyr}$ record was extended to $140 \mathrm{kyr}$ by splicing the hydrologic-balance record from Owens Lake (Menking et al., 1997; Benson, 2003) to the Pyramid Lake record. $\bar{W}_{\text {eff }}$ values of 4.3 and 3.3 were calculated for the past 25 and $140 \mathrm{kyr}$ (Fig. 3).

In order to apply Sierran values of $\bar{W}_{\text {eff }}$ to Colorado sites, we scaled historical snow-depth data from Colorado snow-course sites located at elevations and topographic settings similar to our sampling sites (e.g., the Willow Creek Pass site shown in Fig. 4) using a scaling factor of 4.3 or 3.3. Snow-shielding values were calculated for all north-central Colorado boulders that experienced such hypothetical increases in snow cover. We used a snow density of $0.27 \mathrm{~g} \mathrm{~cm}^{-3}$ and the following equation (Gosse and Phillips, 2001) to calculate the fraction of the cosmic-ray flux reaching the rock surface that lay beneath the snow cover:

$S_{\text {snow on } \mathrm{rx}}=\frac{1}{12} \sum_{i=1}^{i=12} \mathrm{e}^{-\left(\left[D_{\text {snow }, i}-D_{\mathrm{rx}}\right] \rho_{\text {snow }, i}\right) / A_{\mathrm{f}}}$,

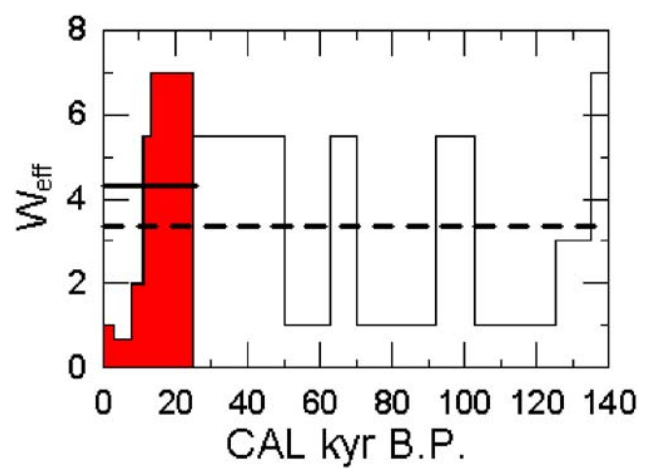

Fig. 3. Estimated effective wetness (relative to historical pristine reconstructions) for the northern Sierra Nevada, California. Shaded area indicates the history of effective wetness experienced by the Lake Lahontan area, Nevada and California, for the past $25 \mathrm{kyr}$. Solid line denotes the mean effective wetness for the past $25 \mathrm{kyr}$; dashed line denotes the mean effective wetness for the past $140 \mathrm{kyr}$. 


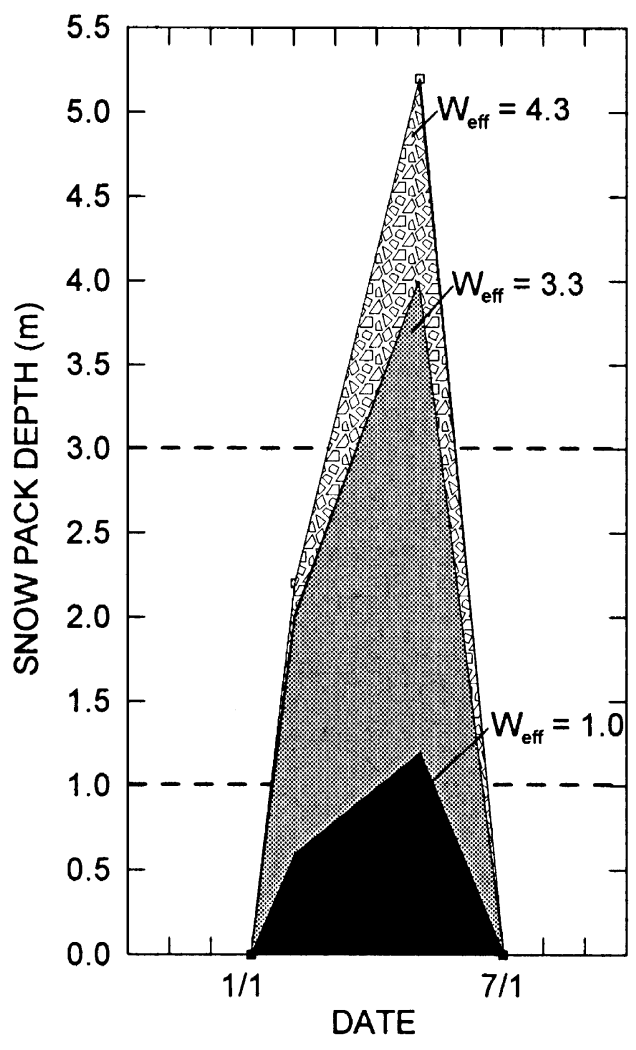

Fig. 4. Willow Creek Pass (elevation $2908 \mathrm{~m}$ ) snowpack depths scaled to $3.3 \times$ and $4.3 \times$ historical mean values for the months February, March, April, and May. The historical snowpack has a mean depth of $0.94 \mathrm{~m}$.

where $S_{\text {snow on rx }}$ is the annual snow shielding, $D_{\text {snow }, i}-$ $D_{\text {rx }}$ is the monthly amount of snow cover on the rock surface, $\rho_{\text {snow }, i}$ is the density of the snow pack $\left(\sim 0.27 \mathrm{~g} \mathrm{~cm}^{-3}\right)$, and $A_{\mathrm{f}}$ is the snow-free cosmic-ray-flux attenuation length.

\section{Results}

In this section we first compare the ${ }^{36} \mathrm{Cl}$ ages of three boulders from the Middle Boulder Creek area using two different sets of ${ }^{36} \mathrm{Cl}$ production values. We then compare the ${ }^{36} \mathrm{Cl}$ age estimates of five boulders with their ${ }^{10} \mathrm{Be}$ age estimates. Given the complexity of ${ }^{36} \mathrm{Cl}$ production, the ${ }^{10} \mathrm{Be}$ dates are used to demonstrate the relative accuracy of the ${ }^{36} \mathrm{Cl}$ results. After showing that applications of the various age-estimation methods do not result in significant age differences, we use the Phillips et al. (1996, 2001)-based ${ }^{36} \mathrm{Cl}$ ages in calculations of the effects of erosion and snow shielding on the ages of Pinedale and pre-Pinedale boulders.

\subsection{Comparison of ${ }^{36} \mathrm{Cl}$ ages based on different production values}

The Middle Boulder Creek samples evaluated using the production values of Stone et al. (1996) and Evans et al. (1997) resulted in ${ }^{36} \mathrm{Cl}$ age estimates that differed by $\leqslant 1 \mathrm{kyr}$ from ${ }^{36} \mathrm{Cl}$ ages based on the Phillips et al. $(1996,2001)$ production values (Table 2). Therefore, in the following, we use the ${ }^{36} \mathrm{Cl}$ ages that are based on the production values of Phillips et al. (1996, 2001).

\subsection{Comparison of ${ }^{36} \mathrm{Cl}$ and ${ }^{10}$ Be age estimates}

Zero-erosion ${ }^{10} \mathrm{Be}$ ages of four Pinedale boulders differ from the Phillips et al. $(1996,2001)$-based ${ }^{36} \mathrm{Cl}$ zero-erosion age estimates by $0.0-2.6 \mathrm{kyr}$ (Table 2 ). The only sample that might be argued to have a ${ }^{10} \mathrm{Be}$ date significantly younger than its ${ }^{36} \mathrm{Cl}$ counterpart is RF-012. If so, this would imply that the surface of RF-01-2 has been eroded and that the true date of surface exposure should fall somewhere between 25.8 and $23.2 \mathrm{kyr}$. However, the fact that the exposure age of this boulder is significantly older than all other Roaring Fork boulder exposure ages suggests that the boulder contains inherited ${ }^{36} \mathrm{Cl}$ and ${ }^{10} \mathrm{Be}$.

\subsection{Comparison of ${ }^{36} \mathrm{Cl}$ ages with continental and Sierran ice records}

Five pre-Pinedale boulders have ${ }^{36} \mathrm{Cl}$ ages ranging from 87 to $144 \mathrm{kyr}$ B.P. (Table 2). Only the $144 \mathrm{kyr}$ date (MBC-01-3) falls within a "glacial" period; i.e., marineisotope stage (MIS) 6 (Martinson et al., 1987). The four other pre-Pinedale boulders (NSV-01-1, RF-01-10, RF01-11, and NSV-01-3) have surface-exposure ages that fall within MIS 5, a period in which global sea-level records indicate that continental ice sheets were small (Shackleton, 1987) and Sierra Nevada ice fields were small or nonexistent (Bischoff et al., 1997) (Fig. 5). We also plotted the ${ }^{36} \mathrm{Cl}$ ages of Bull Lake boulders from the Wind River Range, Wyoming (Phillips et al., 1997) (Fig. 5B). Only 8 of 30 boulders have surface-exposure ages that fall within MIS 4 or 6 .

\subsection{Processes leading to anomalous ${ }^{36} \mathrm{Cl}$ ages}

There are several reasons why a boulder surface may have a ${ }^{36} \mathrm{Cl}$ age that is younger or older than expected, including inheritance, erosion of the boulder surface, and shielding (by snow or sediment), and ${ }^{36} \mathrm{Cl}$ leakage. Inheritance occurs when a rock fails to lose the cosmogenic signature acquired prior to transport by glacier ice. For example, erosion may not remove all of the inherited ${ }^{36} \mathrm{Cl}$ from a glacial boulder remobilized during a subsequent glacial advance. This results in ${ }^{36} \mathrm{Cl}$ ages that are older than the time of boulder deposition.

Surface erosion can either increase or decrease the ${ }^{36} \mathrm{Cl}$ age of a boulder surface. The apparent ${ }^{36} \mathrm{Cl}$ age of a boulder increases with erosion to a depth of $\sim 15 \mathrm{~cm}$, which is the depth of the production maximum resulting from thermal and epithermal neutron absorption 

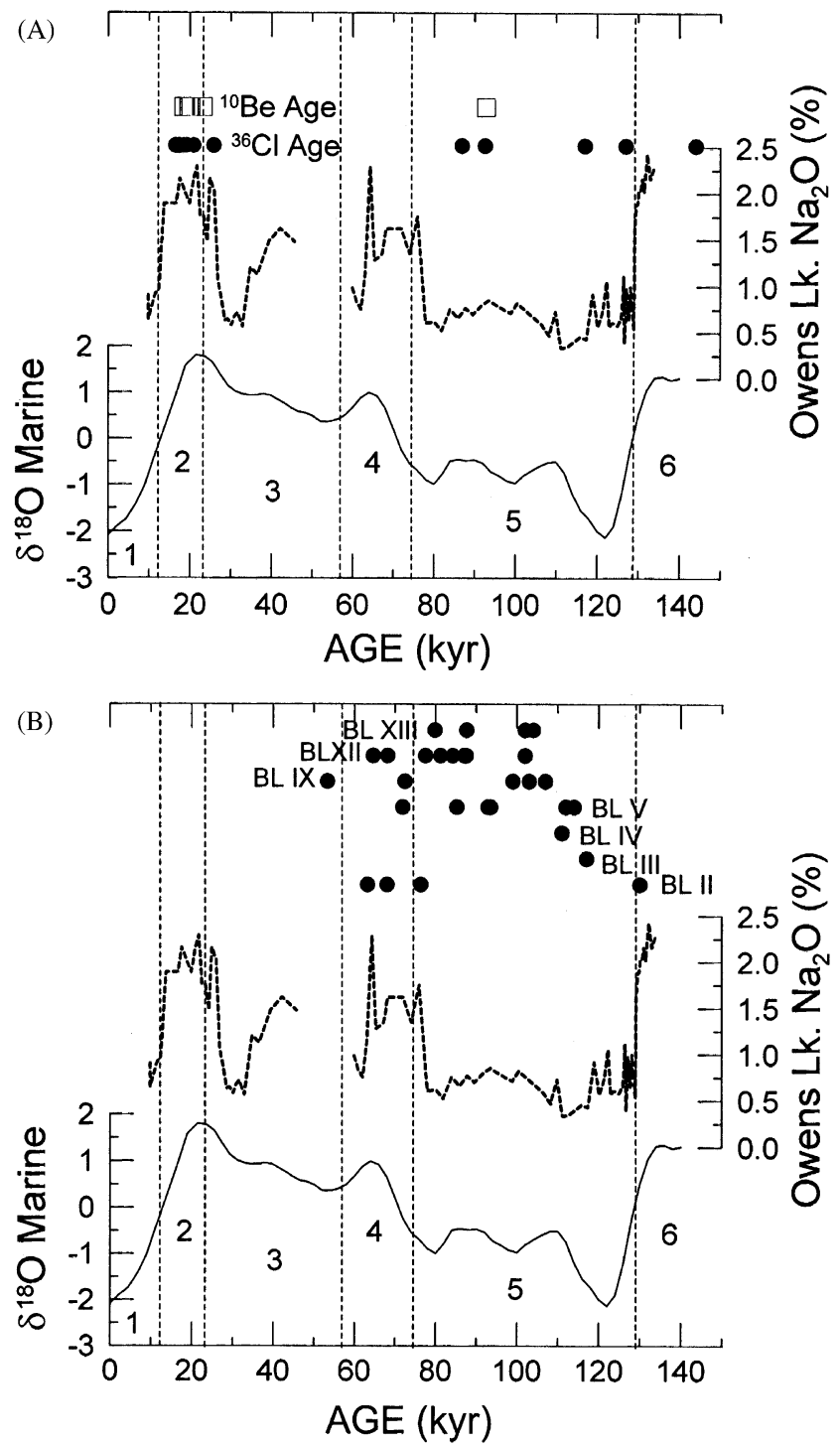

Fig. 5. Uncorrected ${ }^{10} \mathrm{Be}$ and ${ }^{36} \mathrm{Cl}$ ages of boulder surfaces from northcentral Colorado (A) and Wyoming (B) plotted together with an Owens Lake proxy indicator $\left(\mathrm{Na}_{2} \mathrm{O}\right)$ of Sierran alpine glaciation (dashed line) and a marine proxy indicator $\left(\delta^{18} \mathrm{O}\right)$ of continental ice volume. Increasingly positive values of both indicators indicate greater ice volumes. Bull Lake sequences in Wyoming are prefaced with a BL.

(Fig. 6). With increasing depth, the apparent age decreases exponentially. ${ }^{2}$ For the most part, Pinedale boulders have not undergone severe surface erosion. Caine (1979) monitored the weathering of crushed rhyodacite in a broad range of microenvironments, above treeline, in the San Juan Mountains of southwestern Colorado over a 5-year period. His data indicated a mean rate of rock-surface retreat of $0.00055 \mathrm{~mm} \mathrm{yr}^{-1}$. Benedict (1993) measured phenocryst relief on a southwest-facing granodiorite in a col located

\footnotetext{
${ }^{2}$ Erosion down to a depth of $\sim 30 \mathrm{~cm}$ in NSV-01-1 will produce apparent ${ }^{36} \mathrm{Cl}$ ages that are too old.
}

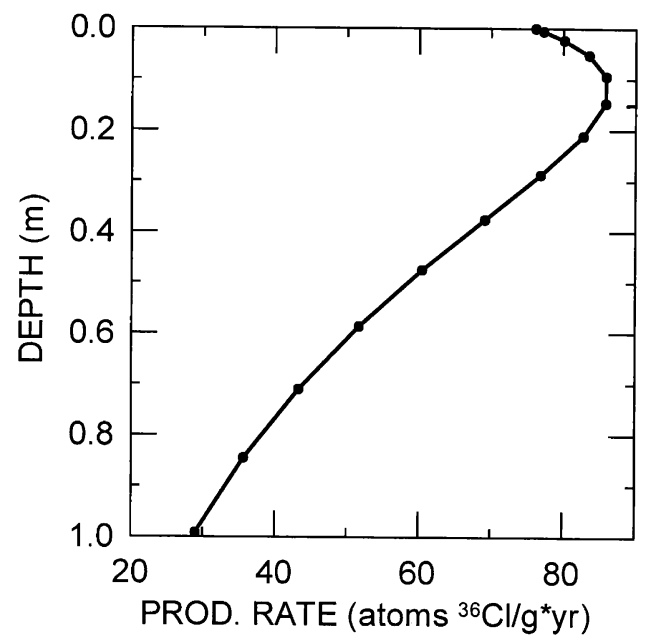

Fig. 6. Simulated production rate plotted as a function of depth below the upper surface of boulder NSV-01-1. Note the maximum in production at $\sim 15 \mathrm{~cm}$. For erosion confined to the upper $30 \mathrm{~cm}$, the apparent ${ }^{36} \mathrm{Cl}$ age will be too old and for erosion below $30 \mathrm{~cm}$, the apparent ${ }^{36} \mathrm{Cl}$ age will be too young.

at an elevation of $3505 \mathrm{~m}$ in the northern Front Range of Colorado. For conditions in which present-day snowcover is less than $\sim 30$ weeks during the year, maximum pheoncryst relief averaged $\sim 10 \mathrm{~mm}$. If we assume that the Pinedale glacier had disappeared from this area between 12 and 14 cal kyr B.P. (see Section 3 above), the mean rate of rock-surface retreat was somewhere between $\sim 0.7$ and $\sim 0.8 \mathrm{~mm} \mathrm{kyr}^{-1}$. In order to correct for rock-surface retreat, erosion rates of 0.5 and $1.0 \mathrm{~mm} \mathrm{kyr}^{-1}$ were used in calculating ${ }^{36} \mathrm{Cl}$ ages. The two erosion rates decreased the apparent ${ }^{36} \mathrm{Cl}$ ages of boulders analyzed in this study by $100-500 \mathrm{yr}$ $\left(0.5 \mathrm{~mm} \mathrm{kyr}^{-1}\right.$ rate $)$ and by $100-1000 \mathrm{yr}\left(1.0 \mathrm{~mm} \mathrm{kyr}^{-1}\right.$ rate) (Table 2).

Because some granite boulders may sporadically spall, the effect of rate of spall on the calculated ${ }^{36} \mathrm{Cl}$ age was estimated. A line was fit to the ${ }^{36} \mathrm{Cl}$ production rate (atoms $\mathrm{Cl} \mathrm{g}^{-1} \mathrm{yr}^{-1}$ ) for RF-01-2 and the fit line was used to increment the production values at $0.1-$ and $1-\mathrm{mm}$ depth intervals. The ${ }^{36} \mathrm{Cl}$ inventory of a sample with an apparent age of $25 \mathrm{kyr}$ (value calculated assuming zero erosion) was created by multiplying the annual production rate by 25,000 . Erosion simulations were conducted at a mean rate of $1 \mathrm{~mm} \mathrm{kyr}^{-1}$, assuming three different rates of spall $\left(0.1 \mathrm{~mm} 100 \mathrm{yr}^{-1}, 1 \mathrm{~mm} \mathrm{kyr}^{-1}\right.$, and $5 \mathrm{~mm}$ $\left.5 \mathrm{kyr}^{-1}\right)$. The lowest rate of spall is thought to approximate continuous erosion. The sample age (integrated production over the top $25 \mathrm{~mm}$ of sample) decreased slightly as a function of spall rate; i.e., from 26.07 to 25.90 to $25.75 \mathrm{kyr}$ for the three rates, suggesting that the assumption of continuous erosion does not greatly affect the calculated age of a Pinedale sample that may have eroded discontinuously by spalling.

It appears improbable, during MIS 5 (see Section 5.3), that valley glaciers were large enough to transport 
boulders NSV-01-1, NSV-01-3, and RF-01-11 to their present locations: therefore, the erosion rate in CHLOE was varied in order to shift the apparent ${ }^{36} \mathrm{Cl}$ ages of these boulders to MIS 4 or MIS 6. Sharp et al. (2003) have recently shown that the glaciofluvial terrace WR3 in the Wind River Basin, which formed penecontemporaneously with the final maximum Bull Lake glacial advance, has a ${ }^{230} \mathrm{Th} / \mathrm{U}$ age of $150 \pm 8.3 \mathrm{kyr}$ age when corrected for incision. This finding suggests that the Bull lake glaciation was broadly synchronous with the penultimate global ice volume maximum during MIS 6 and did not occur during MIS 5.

Dates of 60 and $140 \mathrm{kyr}$ were arbitrarily selected as the times the boulders would have been deposited during MIS 4 or MIS 6. MIS 4 ages for the samples could not be obtained by varying the rate of erosion; however, calculations indicated that erosion rates of 5.9, 6.6, and $10.7 \mathrm{~mm} \mathrm{kyr}^{-1}$ could reduce the estimated ages of 140 kyr-old boulders to the observed values $(87,127$, and $117 \mathrm{kyr}$, Table 2). The calculated erosion rates seem excessive given that Pinedale boulders selected for cosmogenic dating generally appear to have been eroded at rates $\leqslant 1 \mathrm{~mm} \mathrm{kyr}^{-1}$. Even though physical weathering of boulders may have been more rapid between 15 and $75 \mathrm{kyr}$, when the snowpack was estimated to be much thicker than today, it is difficult to call on such rapid rates of weathering to explain these anomalous ages; i.e., these rates of weathering would have removed $0.8-1.5 \mathrm{~m}$ from the surfaces of these boulders during the past $140 \mathrm{kyr}$. In fact, Dahl (1967) showed that granite bedrock surfaces that were snow covered for most of the year showed much less weathering than other surfaces at the same elevation. Benedict (1993) also showed that granodiorite weathering is least effective beneath late-lying snowbanks that protect the rock from freeze-thaw and wetting-drying cycles. Their data argue for lower weathering rates during the somewhat wetter MIS 5 period.

Pre-Pinedale samples were much easier to trim with a diamond saw than Pinedale samples. In addition, the pre-Pinedale samples tended to break apart when sawing, suggesting that they possess a significant amount of secondary porosity. We offer the hypothesis that $\mathrm{Cl}$ leaching may have accompanied and followed the development of porosity. If ${ }^{36} \mathrm{Cl}$ has been preferentially leached from a sample, relative to the $\mathrm{Ca}$ and $\mathrm{K}$ from which the ${ }^{36} \mathrm{Cl}$ formed, the ${ }^{36} \mathrm{Cl}$ age would underestimate the original time of exposure.

The above discussion suggests that other processes, such as snow shielding, sediment shielding, and ${ }^{36} \mathrm{Cl}$ leakage may have been responsible for the relatively young surface ages of NSV-01-1, NSV-01-3, and RF-0111. The young ${ }^{36} \mathrm{Cl}$ age of RF-01-10 ( $\left.~ 93 \mathrm{kyr}\right)$ may also be due to some combination of snow and sediment shielding. But the age cannot be explained by ${ }^{36} \mathrm{Cl}$ leakage or rock-surface erosion because the sample possesses a nearly identical ${ }^{10} \mathrm{Be}$ age (Table 2).

As mentioned previously, pre-Pinedale end moraines have lower and broader profiles than Pinedale end moraines. The low profiles of pre-Pinedale moraines may be the result of slope erosion or mass movement (Hallet and Putkonen, 1994) and may involve postdepositional disturbance of boulders such as rolling or overturning. The rate of erosion of till matrix is high compared to that of boulder surfaces; therefore, some boulders now resting on pre-Pinedale moraines are likely to have been exhumed since their deposition. In addition, mean snow depths must have been higher during MIS 2, 3, and 4 ( $\sim 13$ to $75 \mathrm{kyr}$ BP, Fig. 5) than during the past $50 \mathrm{yr}$.

Whereas it is not possible to directly determine the effects of sediment shielding on the boulders investigated in this paper, approximate snow-shielding values can be applied to all samples assuming changes in $\bar{W}_{\text {eff }}$ discussed in Section 5.4. For most (six) Pinedale boulders, snow-shielding corrections yielded age increases ranging from 1.6 to $3.0 \mathrm{kyr}$; and for three prePinedale boulders, snow-shielding corrections yielded age increases ranging from 10 to $13 \mathrm{kyr}$. Only for boulders whose upper surfaces stand well above presentday snowpack (e.g. NSV-01-1, NSV-01-3, and NSV-014) was the shielding correction minimal relative to the apparent age of the sample (Table 2). The snowshielding corrections for smaller pre-Pinedale boulders surfaces are substantial; however, they are not enough by themselves to produce MIS 6 ages. This suggests that soil shielding and perhaps ${ }^{36} \mathrm{Cl}$ leakage has affected most of the pre-Pinedale boulder surfaces examined in this paper; i.e., boulders have emerged from the coarse till in which they were deposited or have rolled since their deposition or exhumation.

\section{Summary and conclusions}

Uncorrected ${ }^{36} \mathrm{Cl}$ ages of eight Pinedale boulders in north-central Colorado fall in the range 16.5-20.9 kyr (sample RF-01-2, which is believed to have acquired inherited ${ }^{36} \mathrm{Cl}$, was excluded from this data set). ${ }^{10} \mathrm{Be}$ age determinations on four boulder surfaces are in close agreement with ${ }^{36} \mathrm{Cl}$ determinations, suggesting that surface erosion has been minimal during the past $\sim 22$ kyr. Corrections for snow shielding increased the ${ }^{36} \mathrm{Cl}$ ages of Colorado boulders by as much as $3 \mathrm{kyr}$, with increases in age averaging $2.2 \mathrm{kyr}(12 \%$ of the apparent age). The magnitude of this correction, although only an approximation, illustrates the importance of snow shielding on boulders whose heights are not significantly greater than the height of the mean historical snowpack. Without accounting for snow shielding on such relatively small boulders, it may prove 
difficult to match moraine ages with millennial-scale phenomena such as Dansgaard-Oeschger or Heinrich events.

Most ages for Colorado and Wind River, Wyoming, pre-Pinedale (Bull Lake) boulders fall within MIS 5, a time when continental and Sierran ice accumulations were small or nonexistent. Under the assumption that the Colorado boulders were deposited on moraines that formed near the end of MIS 6 (i.e., $140 \mathrm{kyr}$ ), calculations indicate that rock-surface erosion rates would have had to range from 5.9 to $10.7 \mathrm{~mm} \mathrm{kyr}^{-1}$ to produce the apparent ${ }^{36} \mathrm{Cl}$ values present in the top $2-3 \mathrm{~cm}$ of these rocks. If correct, these calculations indicated that from 0.8 to $1.5 \mathrm{~m}$ of the surfaces of the boulders were removed during the past $140 \mathrm{kyr}$. However, the calculated erosion rates can be argued to be anomalously rapid when compared to rates that have been documented for the past $20 \mathrm{kyr}$. In addition, snow shielding only accounts for $0-48 \%$ of the additional years needed to shift prePinedale dates to MIS 6. This suggests that sediment shielding and perhaps ${ }^{36} \mathrm{Cl}$ leakage has decreased the apparent surface ages of most pre-Pinedale boulders described in this paper. Given that the rate of erosion of till matrix is rapid compared to that of boulder surfaces, it is probable that the upper surfaces of many boulders found on pre-Pinedale moraines were exposed to cosmic radiation some time after they were deposited. The inability to determine the magnitudes of snow and sediment shielding that affected pre-Pinedale boulder surfaces thus creates significant uncertainty about using their apparent cosmogenic ages as accurate estimators of the timing of middle-Pleistocene alpine glaciation.

\section{Acknowledgements}

We thank John Andrews and James Benedict for their helpful reviews of an earlier version of this manuscript and we express our appreciation to Joe Licciardi and Peter Clark for their comments and suggestions. We also thank Mitchell Plummer and Fred Phillips for use of the CHLOE program and assistance with its application. We much appreciated Jeremy Havens assistance in the creation of Figs. 1 and 2. The use of firm, trade, and brand names in this report is for identification purposes only and does not imply endorsement by the USGS.

\section{Appendix A. Chlorine analytical data}

$\mathrm{Cl}$ Analytical are presented in Table 4 .

\section{Appendix B. Beryllium analytical data}

Be analytical data are presented in Table 5 .

Table 4

\begin{tabular}{|c|c|c|c|c|c|c|c|c|c|c|}
\hline \multirow[t]{2}{*}{ NAME } & \multirow[t]{2}{*}{ CAMS \# } & \multirow[t]{2}{*}{ S FOM } & \multicolumn{2}{|c|}{${ }^{36} \mathrm{Cl} /{ }^{37} \mathrm{Cl}$ ratio } & \multicolumn{2}{|c|}{ Background } & \multicolumn{2}{|c|}{ Bkgd-corrected } & \multicolumn{2}{|c|}{${ }^{35} \mathrm{Cl} /{ }^{37} \mathrm{Cl}$ ratio } \\
\hline & & & Ratio & \pm & Ratio & \pm & Ratio & \pm & Ratio & \pm \\
\hline MBC-01-1 & CL10160 & 0.999 & $2.598 \mathrm{E}-12$ & $6.11 \mathrm{E}-14$ & $8.21 \mathrm{E}-14$ & $1.23 \mathrm{E}-14$ & $2.518 \mathrm{E}-12$ & $6.24 \mathrm{E}-14$ & 5.55 & 0.001 \\
\hline MBC-01-2 & CL10161 & 0.999 & $3.375 \mathrm{E}-12$ & $7.93 \mathrm{E}-14$ & $8.21 \mathrm{E}-14$ & $1.23 \mathrm{E}-14$ & $3.295 \mathrm{E}-12$ & $8.03 \mathrm{E}-14$ & 5.77 & 0.004 \\
\hline MBC-01-3 & CL10162 & 1.000 & $1.042 \mathrm{E}-11$ & $1.81 \mathrm{E}-13$ & $8.21 \mathrm{E}-14$ & $1.23 \mathrm{E}-14$ & $1.035 \mathrm{E}-11$ & $1.82 \mathrm{E}-13$ & 5.65 & 0.007 \\
\hline NSV-01-1 & CL10163 & 1.000 & $1.433 \mathrm{E}-11$ & $2.49 \mathrm{E}-13$ & $8.21 \mathrm{E}-14$ & $1.23 \mathrm{E}-14$ & $1.426 \mathrm{E}-11$ & $2.49 \mathrm{E}-13$ & 4.28 & 0.001 \\
\hline NSV-01-2 & CL10164 & 0.999 & $6.578 \mathrm{E}-12$ & $1.44 \mathrm{E}-13$ & $8.21 \mathrm{E}-14$ & $1.23 \mathrm{E}-14$ & $6.500 \mathrm{E}-12$ & $1.44 \mathrm{E}-13$ & 5.75 & 0.001 \\
\hline NSV-01-3 & CL10165 & 1.000 & $1.435 \mathrm{E}-11$ & $2.49 \mathrm{E}-13$ & $8.21 \mathrm{E}-14$ & $1.23 \mathrm{E}-14$ & $1.427 \mathrm{E}-11$ & $2.49 \mathrm{E}-13$ & 4.68 & 0.000 \\
\hline NSV-01-3d & CL10166 & 1.000 & $1.414 \mathrm{E}-11$ & $2.22 \mathrm{E}-13$ & $8.21 \mathrm{E}-14$ & $1.23 \mathrm{E}-14$ & $1.406 \mathrm{E}-11$ & $2.22 \mathrm{E}-13$ & 4.64 & 0.003 \\
\hline NSV-01-4 & CL10167 & 0.999 & $5.842 \mathrm{E}-12$ & $1.12 \mathrm{E}-13$ & $8.21 \mathrm{E}-14$ & $1.23 \mathrm{E}-14$ & $5.764 \mathrm{E}-12$ & $1.13 \mathrm{E}-13$ & 5.53 & 0.011 \\
\hline RF-01-2 & CL10169 & 0.999 & $4.821 \mathrm{E}-12$ & $1.12 \mathrm{E}-13$ & $8.21 \mathrm{E}-14$ & $1.23 \mathrm{E}-14$ & $4.742 \mathrm{E}-12$ & $1.13 \mathrm{E}-13$ & 5.89 & 0.004 \\
\hline RF-01-3 & CL10170 & 0.999 & $4.095 \mathrm{E}-12$ & $1.06 \mathrm{E}-13$ & $8.21 \mathrm{E}-14$ & $1.23 \mathrm{E}-14$ & $4.016 \mathrm{E}-12$ & $1.06 \mathrm{E}-13$ & 4.72 & 0.003 \\
\hline RF-01-5 & CL10171 & 0.999 & $4.496 \mathrm{E}-12$ & $1.24 \mathrm{E}-13$ & $8.21 \mathrm{E}-14$ & $1.23 \mathrm{E}-14$ & $4.417 \mathrm{E}-12$ & $1.25 \mathrm{E}-13$ & 5.86 & 0.009 \\
\hline RF-01-6 & CL10172 & 0.999 & $4.729 \mathrm{E}-12$ & $1.76 \mathrm{E}-13$ & $8.21 \mathrm{E}-14$ & $1.23 \mathrm{E}-14$ & $4.650 \mathrm{E}-12$ & $1.76 \mathrm{E}-13$ & 5.49 & 0.010 \\
\hline RF-01-7 & CL10173 & 0.999 & $4.456 \mathrm{E}-12$ & $1.52 \mathrm{E}-13$ & $8.21 \mathrm{E}-14$ & $1.23 \mathrm{E}-14$ & $4.377 \mathrm{E}-12$ & $1.53 \mathrm{E}-13$ & 5.50 & 0.020 \\
\hline RF-01-9 & CL10174 & 0.999 & $3.473 \mathrm{E}-12$ & $9.37 \mathrm{E}-14$ & $8.21 \mathrm{E}-14$ & $1.23 \mathrm{E}-14$ & $3.393 \mathrm{E}-12$ & $9.45 \mathrm{E}-14$ & 5.82 & 0.010 \\
\hline RF-01-10 & CL10175 & 1.000 & $1.689 \mathrm{E}-11$ & $6.08 \mathrm{E}-13$ & $8.21 \mathrm{E}-14$ & $1.23 \mathrm{E}-14$ & $1.681 \mathrm{E}-11$ & $6.08 \mathrm{E}-13$ & 4.69 & 0.005 \\
\hline RF-01-11 & CL10176 & 1.000 & $2.642 \mathrm{E}-11$ & $6.20 \mathrm{E}-13$ & $8.21 \mathrm{E}-14$ & $1.23 \mathrm{E}-14$ & $2.636 \mathrm{E}-11$ & $6.20 \mathrm{E}-13$ & 5.49 & 0.001 \\
\hline AgCl Blank & CL10158 & 0.955 & $8.204 \mathrm{E}-14$ & $1.230 \mathrm{E}-14$ & & & $8.209 \mathrm{E}-14$ & $1.230 \mathrm{E}-14$ & 3.16 & 0.003 \\
\hline
\end{tabular}

Note: $1 .{ }^{36} \mathrm{Cl} / \mathrm{Cl}$ ratios were normalized to a standard (KNSTD) with a ${ }^{36} \mathrm{Cl} / \mathrm{Cl}$ ratio of $1.60 \mathrm{E}-12$.

2. Ratios were corrected for spurious counts resulting from sulfur contamination in the sample. A sulfur figure of merit of 1 indicates that there were no spurious counts, an FOM of .95 corresponds to a $5 \%$ sulfur correction, etc. The FOM does not correct for the count rate suppression that can occur at high $S$ rates.

3. Background-corrected ratios were calculated using the backgrounds indicated, based on measured blank CL10158.

4. ${ }^{35} \mathrm{Cl} /{ }^{37} \mathrm{Cl}$ ratios were measured relative to standards with an assumed natural $35 / 37$ ratio of 3.127 . The uncertainty quoted reflects the standard deviation of the multiple measurements for each sample. 
Table 5

\begin{tabular}{|c|c|c|c|c|c|c|c|c|}
\hline Sample ID & AMS ID & $\begin{array}{l}{ }^{10} \mathrm{Be} /{ }^{9} \mathrm{Be} \\
\left(\times 10^{-12}\right)\end{array}$ & $\begin{array}{l}\text { Error } \\
(\%)\end{array}$ & $\begin{array}{l}\text { Be carrier } \\
(\mathrm{mg})\end{array}$ & $\begin{array}{l}\text { Sample mass } \\
(\mathrm{g})\end{array}$ & ${ }^{10} \mathrm{Be}^{\mathrm{a}}\left(\right.$ atoms $\left./ \mathrm{g} \times 10^{4}\right)$ & $\begin{array}{l}\text { Thickness } \\
(\mathrm{cm})\end{array}$ & Scaling factor ${ }^{\mathrm{b}}$ \\
\hline NSV-1-4 & ZB2233 & 0.7681 & 4.80 & 0.3559 & 26.021 & 67.06 & 4.0 & 6.61 \\
\hline RF-1-2 & ZB2234 & 0.6311 & 4.00 & 0.3575 & 17.940 & 79.46 & 5.4 & 6.74 \\
\hline RF-1-5 & ZB2235 & 1.1700 & 4.00 & 0.3573 & 38.050 & 71.26 & 4.0 & 6.89 \\
\hline RF-1-9 & ZB2236 & 0.7141 & 4.00 & 0.3579 & 24.734 & 65.72 & 4.4 & 6.95 \\
\hline RF-1-10 & ZB2237 & 3.8029 & 4.70 & 0.3566 & 27.898 & 321.88 & 2.4 & 6.77 \\
\hline
\end{tabular}

The AMS results have been normalized to Zurich ETH standard S555 with a nominal value of ${ }^{10} \mathrm{Be} / \mathrm{Be}=95.5 \times 10^{-12}$.

This is a secondary standard normailzed to the material BEST433 (H. Hofmann et al, Nucl. Instr. and Meth. B29 (1987) 32-36).

The uncertainty of this standard (about $2.5 \%$ ) is not included in the quoted uncertainties of the samples.

Quoted error is $1 \sigma$.

${ }^{\mathrm{a}}$ Value corrected for beryllium procedural blank value of $0.0344 \times 10-12 \pm 15 \%$.

${ }^{\mathrm{b}}$ Production rate scaling factor computed after Stone (2000) for sample geographic latitude and altitude.

\section{References}

Bard, E., Arnold, M., Hamelin, B., Tisnerat-Laborde, N., Cabioch, G., 1998. Radiocarbon calibration by means of mass spectrometric ${ }^{230} \mathrm{TH} /{ }^{234} \mathrm{U}$ and ${ }^{14} \mathrm{C}$ ages of corals: an updated database including samples from Barbados, Mururoa and Tahiti. Radiocarbon 40, 1085-1092.

Benedict, J.B., 1993. Influence of snow upon rates of granodiorites weathering, Colorado Front Range, USA. Boreas 22, 87-92.

Benson, L., 2003. Western lakes. In: Gillespie, A.R., Porter, S.C., Atwater, B. (Eds.), Quaternary of the United States. Elsevier, Amsterdam, pp. 185-204, Chapter 12.

Benson, L., Peterman, 1995. Carbonate deposition, Pyramid Lake subbasin, Nevada: 3 . the use of ${ }^{87} \mathrm{Sr}$ values in carbonate deposits (tufas) to determine the hydrologic state of paleolake systems. Palaeogeography, Palaeoclimatology, Palaeoecology 119, 201-213.

Benson, L., Kashgarian, Rubin, M., 1995. Carbonate deposition Pyramid Lake subbasin Nevada: 2. Lake levels and polar jet stream positions reconstructed from radiocarbon ages and elevations of carbonates (tufas) deposited in the Lahontan Basin. Palaeogeography, Palaeoclimatology, Palaeoecology 117, 1-30.

Benson, L., Kashgarian, M., Rye, R., Lund, S., Paillet, F., Smoot, J., Kester, C., Mensing, S., Meko, D., Lindstrom, S., 2002. Holocene multidecadal and multicentennial droughts affecting Northern California and Nevada. Quaternary Science Reviews 21, 659-682.

Bischoff, J.L., Menking, K.M., Fitts, J.P., Fitzpatrick, J.A., 1997. Climatic oscillations $10,000-155,000 \mathrm{yr}$ B.P. at Owens Lake, California reflected in glacial rock flour abundance and lake salinity in core OL-92. Quaternary Research 48, 313-325.

Braddock, W.A., Cole, J.C., 1990. Geologic map of Rocky Mountain National Park and vicinity, Colorado. US Geological Survey Miscellaneous Investigation Series Map I-1973, scale 1:50,000.

Caine, N., 1979. Rock weathering rates at the soil surface in an alpine environment. Catena 6, 131-144.

Cerling, T.E., Craig, H., 1994. Cosmogenic ${ }^{3} \mathrm{He}$ production rates from $39^{\circ}$ to $46^{\circ} \mathrm{N}$ latitude, western USA and France. Geochimica et Cosmochimica et Acta 58, 249-255.

Dahl, R., 1967. Post-glacial micro-weathering of bedrock surfaces in the Narvik district of Norway. Geografiska Annaler 49A, 155-166.

Davis, P.T., 1987. Late Pleistocene age for type Triple Lakes moraines, Arapaho Cirque, Colorado Front Range. Geological Society of America Abstracts with Programs 19(5), 270.

Davis, P.T., Birkeland, P.W., Caine, N., Rodbell, D.T., 1992. New radiocarbon ages from cirques in Colorado Front Range. Geological Society of America Abstracts with Programs 24(6), p. A 347.

Evans, J.M., Stone, J.O.H., Fifield, L.K., Cresswell, R.G., 1997. Cosmogenic chlorine-36 production in K-feldspar. Nuclear Instruments and Methods in Physics B 123, 334-340.
Evans, J.M., Stone, J.O.H., Fifield, L.K., Allan, G.L., Cresswell, R.G., 1998. Cosmogenic chlorine-36 production in calcite by muons. Geochimica et Cosmochimica Acta 62, 433-454.

Gable, D.J., 1969. Geologic map of the Nederland quadrangle, Boulder and Gilpin Counties, Colorado. US Geological Survey Geologic Quadrangle Map GQ-833, scale 1:24,000.

Gosse, J.C., Phillips, F.M., 2001. Terrestrial in situ cosmogenic nuclides: theory and application. Quaternary Science Reviews 20, 1475-1560.

Hallet, B., Putkonen, J., 1994. Surface dating of dynamic landforms: young boulders on aging moraines. Science 265, 937-940.

Hughen, K.A., Overpeck, J.T., Lehman, S.J., Kashgarian, M., Southon, J.R., Peterson, L.C., 1998. A new ${ }^{14} \mathrm{C}$ calibration data set for the last deglaciation based on marine varves. Radiocarbon 40, 483-494.

Klein, J., Gosse, J.C., 2002. Production rates of ${ }^{10} \mathrm{Be}$ and ${ }^{26} \mathrm{Al}$ in midlatitudes and high altitudes. Goldschmidt Conference Abstracts, $\mathrm{p}$. 403.

Kubik, P.W., Ivy-Ochs, S., Masarik, J., Frank, M., Sclüchter, C., 1998. ${ }^{10} \mathrm{Be}$ and ${ }^{26} \mathrm{Al}$ production rates deduced from an instantaneous event within the dendro-calibration curve, the landslide of Köfels Ötz, Valley Austria. Earth and Planetary Science Letters 161, 231241.

Legg, T.E., Baker, R.G., 1980. Palynology of Pinedale sediments Devlin Park, Boulder County, Colorado. Arctic and Alpine Research 12, 319-333.

Madole, R.F., 1969. Pinedale and Bull Lake glaciation in upper St. Vrain drainage basin, Boulder county, Colorado. Arctic and Alpine Research 1, 279-287.

Madole, R.F., 1976a. Glacial geology of the Front Range, Colorado. In: Mahaney, W.C. (Ed.), Quaternary Stratigraphy of North America. Dowden, Hutchinson \& Ross Inc, Stroudsburg Pennsylvania, pp. 297-318.

Madole, R.F., 1976b. Bog stratigraphy, radiocarbon dates, and Pinedale to Holocene glacial history in the Front Range, Colorado. U.S. Geological Survey Journal of Research 4, 163-169.

Madole, R.F., 1980. Time of Pinedale glaciation in north-central Colorado: further considerations. Geology 8, 118-122.

Madole, R.F., 1986. Lake Devlin and Pinedale glacial history, Front Range, Colorado. Quaternary Research 25, 43-54.

Madole, R.F., 1991a. Surficial geologic map of the Walden $30^{\prime} \times 60^{\prime}$ quadrangle, Jackson, Larimer, and Routt Counties, Colorado. U.S. Geological Survey Miscellaneous Investigation Series Map I1824, scale $1: 100,000$.

Madole, R.F., 1991b. Surficial geologic map of the Steamboat Springs $30^{\prime} \times 60^{\prime}$ quadrangle, Grand, Jackson, and Routt Counties, Colorado. U.S. Geological Survey Miscellaneous Investigation Series Map I-1825, scale 1:100,000. 
Madole, R.F., Shroba, R.R., 1979. Till sequence and soil development in the North St. Vrain drainage basin, east slope, Front Range, Colorado. In: Ethridge, F.G. (Ed), Field Guide, Northern Front Range and Northwest Denver Basin, Colorado. Fort Collins Department of Earth Resources, Colorado State University, pp. 123-178.

Madole, R.F., VanSistine, D.P., Michael, J.A., 1998. Pleistocene glaciation in the Upper Platte River drainage basin, Colorado. U.S. Geological Survey Geologic Investigations Series I-2644.

Martinson, D.G., Pisias, N.G., Hays, J.D., Imbrie, J., Moore Jr., T.C., Shackleton, N.J., 1987. Age dating ad the orbital theory of the ice ages: development of a high-resolution 0 to 300,000-year chronostratigraphy. Quaternary Research 27, 1-29.

Menking, K.M., Bischoff, J.L., Fitzpatrick, J.A., Burdette, J.W., Rye, R.O., 1997. Climatic/hydrologic oscillations since 155,000 yr B.P. at Owens Lake, California, reflected in abundance and stable isotope composition of sedimentary carbonate. Quaternary Research 48, 58-68.

Menounos, B., Reasoner, M.A., 1997. Evidence for cirque glaciation in the Colorado Front Range during the Younger Dryas chronozone. Quaternary Research 48, 38-47.

Nelson, A.R., Millington, A.C., Andrews, J.T., Nichols, H., 1979. Radiocarbon-dated upper Pleistocene glacial sequence, Fraser Valley, Colorado Front Range. Geology 7, 410-414.

Nichols, H., Short, S.K., Elias, S.A., Harbor, J., 1984. Sedimentation and palynology in high-level lakes, Front Range: Boulder, Colorado. Guidebook for Field Trip 11, Eighth Biennial Meeting, American Quaternary Association, August 1984, 21 pp.

Oviatt, C.G., Currey, D.R., Sack, D., 1992. Radiocarbon chronology of Lake Bonneville, eastern Great Basin, USA. Palaeogeography, Palaeoclimatology, Palaeoecology 99, 225-241.

Phillips, F.M., Plummer, M.A., 1996. CHLOE: a program for interpreting in-situ cosmogenic nuclide data for surface exposure and erosion studies. Radiocarbon 38, 98.

Phillips, F.M., Zreda, M.G., Elmore, D., Sharma, P., 1996. A reevaluation of cosmogenic ${ }^{36} \mathrm{Cl}$ production rates in terrestrial rocks. Geophysical Research Letters 23, 949-952.
Phillips, F.M., Zreda, M.G., Gosse, J.C., Klein, J., Evenson, E.B., Hall, R.D., Chadwick, O.A., Sharma, P., 1997. Cosmogenic ${ }^{36} \mathrm{Cl}$ and ${ }^{10} \mathrm{Be}$ ages of Quaternary glacial and fluvial deposits of the Wind River Range, Wyoming. Geological Society of America Bulletin 109, 1453-1463.

Phillips, F.M., Stone, W.D., Fabryka-Martin, J., 2001. An improved approach to calculating low-energy cosmic ray neutron fluxes near the land/atmosphere interface. Chemical Geology 175, 689-701.

Reasoner, M.A., Jodry, M.A., 2000. Rapid response of alpine timberline vegetation to the Younger Dryas climate oscillation in the Colorado Rocky Mountains, USA. Geology 28, 51-54.

Rosenbaum, J.G., Larson, E.E., 1983. Paleomagnetism of two latePleistocene lake basins in Colorado: an evaluation of detrital remanent magnetization as a recorder of the geomagnetic field. Journal of Geophysical Research 88, 10611-10624.

Schaller, M., von Blanckenburg, F., Hovius, N., Kubik, P.W., 2001. Large-scale erosion rates from in situ-produced cosmogenic nuclides in European river sediments. Earth and Planetary Science Letters $88,441-445$.

Shackleton, N.J., 1987. Oxygen isotopes, ice volume and sea level. Quaternary Science Reviews 6, 183-190.

Sharp, W.D., Ludwig, K.R., Chadwick, O.A., Amundson, R., Glaser, L.L., 2003. Dating fluvial terraces by ${ }^{230} \mathrm{Th} / \mathrm{U}$ on pedogenic carbonate, Wind River Basin, Wyoming. Quaternary Research 59, $139-150$.

Snyder, G.L., 1980. Geologic map of the central part of the northern Park Range, Jackson and Routt Counties, Colorado. U.S. Geological Survey Miscellaneous Investigation Series Map I1112, scale 1:48,000.

Stone, J., 2000. Air pressure and cosmogenic isotope production. Journal of Geophysical Research 105, 23753-23759.

Stone, J., Allan, G.L., Fifield, L.K., Cresswell, 1996. Cosmogenic chlorine-36 from calcium spallation. Geochimica et Cosmochimica Acta 60, 679-692. 